doi:10.20312/dim.2017.05

\title{
A hiperbolikus Kepler-egyenlet geometriai szemléletű tárgyalása
}

\author{
Péntek Kálmán \\ ELTE SEK TTMK Savaria Matematikai Tanszék \\ pentek.kalman@sek.elte.hu
}

\begin{abstract}
ÖSSZEFOGLALÓ. A dolgozatban a hiperbolikus Kepler-egyenlet egy egyszerü bizonyítását mutatjuk be geometriai módszerek alkalmazásával.

ABSTRACT. In the paper, we present a simple proof of the hyperbolical Kepler's Equation with the using of the geometrical methods.
\end{abstract}

\section{Bevezetés}

1609-ben jelent meg Johannes Kepler (1571-1630) német matematikus és csillagász „Astronomia nova” c. mủve. Ebben találhatjuk a később róla elnevezett bolygómozgási törvények közül az első kettő tárgyalását. E korszakalkotó mü 60. fejezetében olvashatjuk a ma már Kepler-egyenletként elhíresült összefüggés levezetését. Kepler a bizonyítás során Szürakuszai Arkhimédesz (Kr.e. 287 - Kr.e. 212) „A konoidokról és szferoidokról”, valamint Alexandriai Euklidesz (Kr.e 365(?) - Kr.e. 300(?)) „Elemek” c. munkájára támaszkodott.

A Kepler-egyenlet matematikai összefüggésként az

$$
E-e \cdot \sin E=\frac{2 \pi}{T}(t-\tau)
$$

alakban írható fel, ahol $E=$ excentrikus anomália, $e=$ pálya excentricitása, $n=\frac{2 \pi}{T}=$ közepes szögsebesség, $\tau=$ perihélium átmenet időpontja és végül $t=$ idő. Ezen egyenlet segítségével képesek vagyunk megmondani, hogy a vizsgált, Nap körül keringő égitest pályájának mely pontján tartózkodik egy adott $t$ időpontban.

Kepler nyomán vált világossá, hogy a nagybolygók a Nap körül ellipszis formájú pályákon haladnak, viszont az ő idejében elfogadott nézet volt az, hogy az üstökösök viszont egyenes mentén haladó égitestek. A mozgások lehetséges pályájaként ekkor még nem vetődött fel a Pergai Apollóniosz (Kr.e. 265(?) - Kr.e. 190(?)) által részletesen vizsgált kúpszeletek ellipszisen kívüli két további típusa, a parabola és a hiperbola alakú pályagörbe.

A XVII. sz. második felében már azt vizsgálták a tudósok, hogy milyen erőhatások tartják egyben a Naprendszert, s mi szabja meg a bolygók pályagörbéjének alakját. Edmond Halley (1656-1742) angol csillagász vetette fel az akkor már vitathatatlan szakmai tekintélyü Sir Isaac Newton (1643-1727) angol fizikus, matematikus és csillagász számára, hogy milyen alakú pályákon kell mozognia a bolygóknak a Nap körül, ha a Nap és a vizsgált bolygó közti vonzóerő az égitestek tömegével egyenes, a köztük levő pillanatnyi távolság négyzetével fordítottan arányos.

Newton válasza lényegében az 1687-ben megjelent „Philosophiae Naturalis Principia Mathematica" c. müvében olvasható. Newton e könyvében kifejtette, hogy a kezdeti feltételektől függően a bolygópályák alakja az Apollóniosz-féle kúpszeletek bármelyike lehet, 
tehát az ellipszis alakú pályák mellett szóba jöhetnek a parabola, illetve hiperbola pályák is. Kiderült például a Naprendszer belső térségeibe érkező számos üstökösről, hogy pályája a pontos megfigyelések szerint elnyúlt parabola, s nem pedig a korábban hitt egyenes.

Ezért indokolt, hogy levezessük minél elemibb, alapvetően geometriai módszerekkel az ellipszisre vonatkozó Kepler-egyenlet hiperbola pályákra vonatkozó megfelelőjét is.

\section{A Gauss formula}

A későbbi részekben felhasználjuk Carl Friedrich Gauss (1777-1855) egy szép összefüggését, amelyet az alábbiakban mutatunk be.

Határozzuk meg egy $m_{1}$ tömegü $P_{1}$ tömegpont (Nap) körül mozgó $m_{2}$ tömegü $P_{2}$ tömegpont (bolygó) által a $\tau_{0}$ és $\tau$ időpontok között súrolt pályacikk területét, ha a két égitest között csak a kölcsönös gravitációs vonzóerő hat!

Jusson a kicsiny $\Delta t$ idő alatt a $P_{2}$ bolygó a $P_{2}{ }^{\prime}$ helyzetbe, jelölje $\Delta v$ a $P_{1} P_{2}$ és $P_{1} P_{2}{ }^{\prime}$ rádiuszvektorok hajlásszögét, $r$ pedig a $P_{1} P_{2}$ távolságot, $\Delta T$ végül a $P_{1} P_{2} P_{2}{ }^{\prime}$ elemi pályacikk területét! Ha ezt az alakzatot körcikkel közelítjük, akkor érvényes rá

$$
\frac{\Delta T}{r^{2} \pi}=\frac{\Delta v}{2 \pi},
$$

amelynek egyszerü átrendezésével

$$
\Delta T=\frac{1}{2} r^{2} \cdot \Delta v
$$

következik. Innen $\Delta t$ értékkel osztva (3) mindkét oldalát

$$
\frac{\Delta T}{\Delta t}=\frac{1}{2} r^{2} \cdot \frac{\Delta v}{\Delta t}
$$

adódik, amely $\Delta t \rightarrow 0$ határátmenettel eredményezi a

$$
\frac{d T}{d t}=\frac{1}{2} r^{2} \cdot \frac{d v}{d t}
$$

összefüggést (1. ábra).

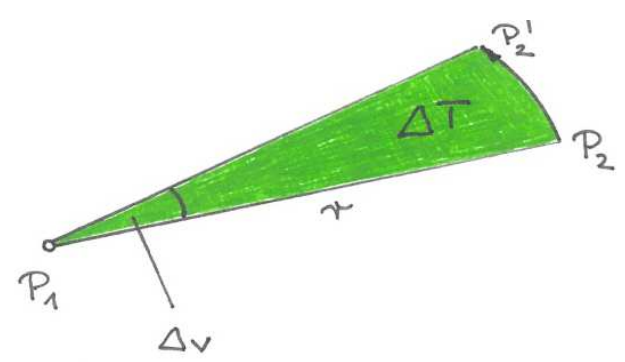

1. ábra. A Gauss-formula

A feladatunkban vizsgált mozgás az égi mechanika egyik klasszikus alapfeladata, a 2-test probléma, amely mint ismeretes ekvivalens az 1-centrum problémával. E problémát leíró 
differenciálegyenlet egyik első integrálja az impulzusmomentum tétel, amely alapján a mozgás síkbeli mozgás, s amelyre fennáll az

$$
r^{2} \frac{d v}{d t}=c(=\mathrm{konstans})
$$

összefüggés. A pálya egyenlete pedig alkalmas koordináta-rendszerben

$$
r=\frac{p}{1+e \cdot \cos v}
$$

polárkoordinátás egyenletü kúpszelet, amelynek paraméterére teljesül még a

$$
p=\frac{c^{2}}{\mu}
$$

összefüggés, ahol $\mu=k^{2}\left(m_{1}+m_{2}\right)$ és itt $k$ a Gauss-féle gravitációs konstans. A (8) összefüggés egyszerü étrendezésével

$$
c=\sqrt{\mu \cdot p}
$$

következik, amelynek (6) formulával történő egybevetéséből

$$
r^{2} \frac{d v}{d t}=\sqrt{\mu \cdot p}
$$

következik. Most az (5) és (10) összefüggésekből

$$
\frac{d T}{d t}=\frac{1}{2} \sqrt{\mu p}
$$

adódik, amelyből

$$
d T=\frac{1}{2} \sqrt{\mu p} \cdot d t
$$

majd pedig (12) idő szerinti integrálásával a $\left[\tau_{0}, \tau\right]$ időintervallumra kapjuk meg a

$$
T=\frac{1}{2} \sqrt{\mu p} \cdot\left(\tau-\tau_{0}\right)
$$

összefüggést, amelyet az égi mechanika Gauss-formulájának nevezünk (2. ábra).

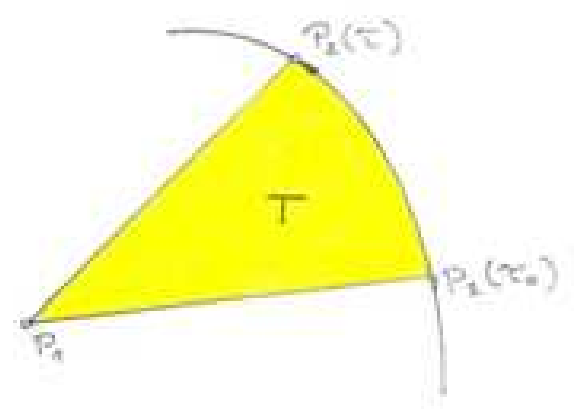

2. ábra. A pályaszektor 


\section{A hiperbolikus Kepler egyenlet}

Mozogjon az $m_{1}$ tömegü $P_{1}$ tömegpont, mint fókuszpont körül hiperbola pályán az $m_{2}$ tömegü $P_{2}$ tömegpont. A hiperbola pálya paraméteres egyenletrendszere alkalmas koordinátarendszerben

$$
\left.\begin{array}{l}
x=a \cdot \operatorname{ch} t \\
y=b \cdot \operatorname{sh} t
\end{array}\right\}
$$

továbbá mivel

$$
\left.\begin{array}{l}
\frac{d x}{d t}=a \cdot \operatorname{sh} t \\
\frac{d y}{d t}=b \cdot \operatorname{ch} t
\end{array}\right\}
$$

ezért az $O P P_{2}$ hiperbolaszektor területe (3. ábra)

$$
\begin{gathered}
T=\frac{1}{2} \int_{0}^{t}\left(x \cdot \frac{d y}{d t}+y \cdot \frac{d x}{d t}\right) d t=\frac{1}{2} \int_{0}^{t}(a \cdot \operatorname{ch} t \cdot b \cdot \operatorname{ch} t-b \cdot \operatorname{sh} t \cdot a \cdot \operatorname{sh} t) d t= \\
=\frac{a \cdot b}{2} \int_{0}^{t} \underbrace{\left(c h^{2} t-\operatorname{sh}^{2} t\right)}_{1} d t=\frac{a \cdot b}{2}[t]_{0}^{t}=\frac{1}{2} a \cdot b \cdot t .
\end{gathered}
$$

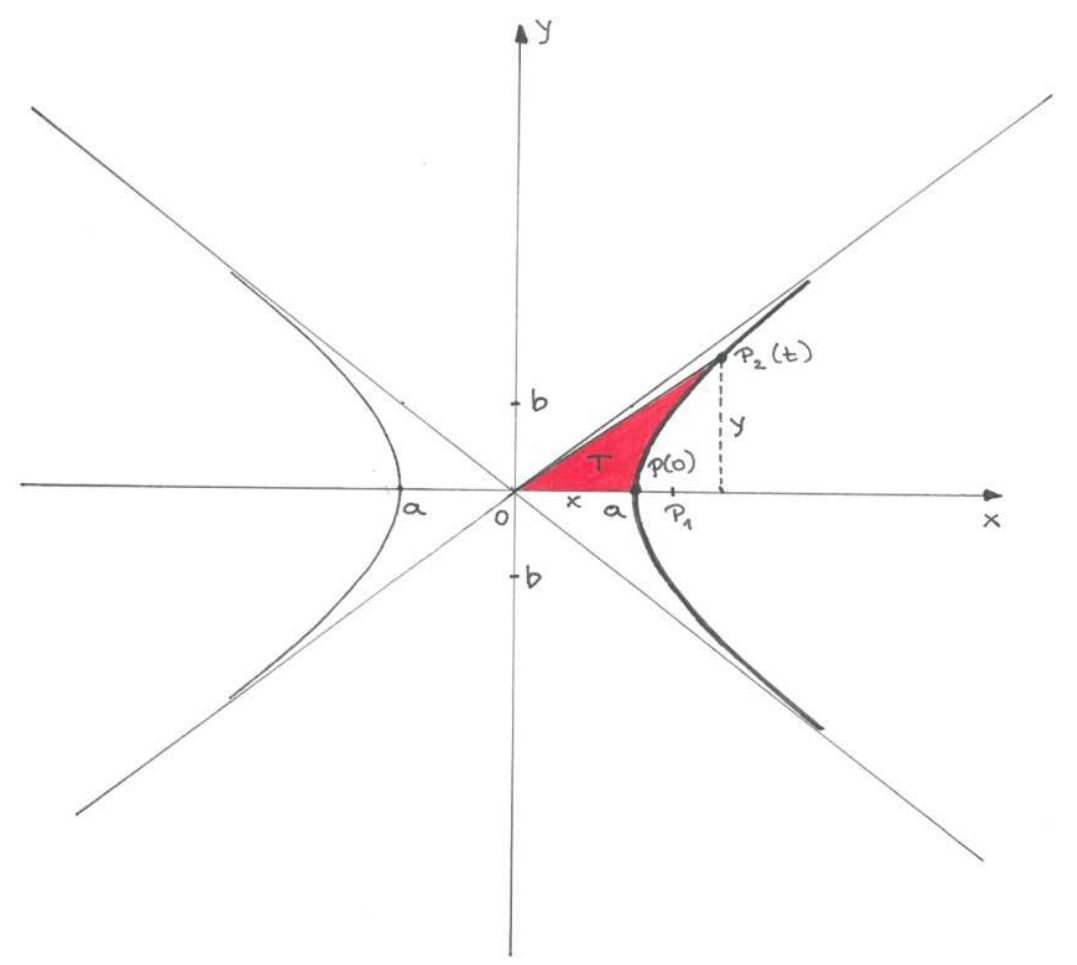

3. ábra. A hiperbola szektor

A $P M P_{2}$ hiperbolaszelet területe (4. ábra):

$$
S=T_{O M P_{2} \Delta}-T=\frac{1}{2} \cdot a \cdot \operatorname{ch} t \cdot b \cdot \operatorname{sh} t-\frac{1}{2} a \cdot b \cdot t=\frac{a \cdot b}{2}(\operatorname{ch} t \cdot \operatorname{sh} t-t) .
$$




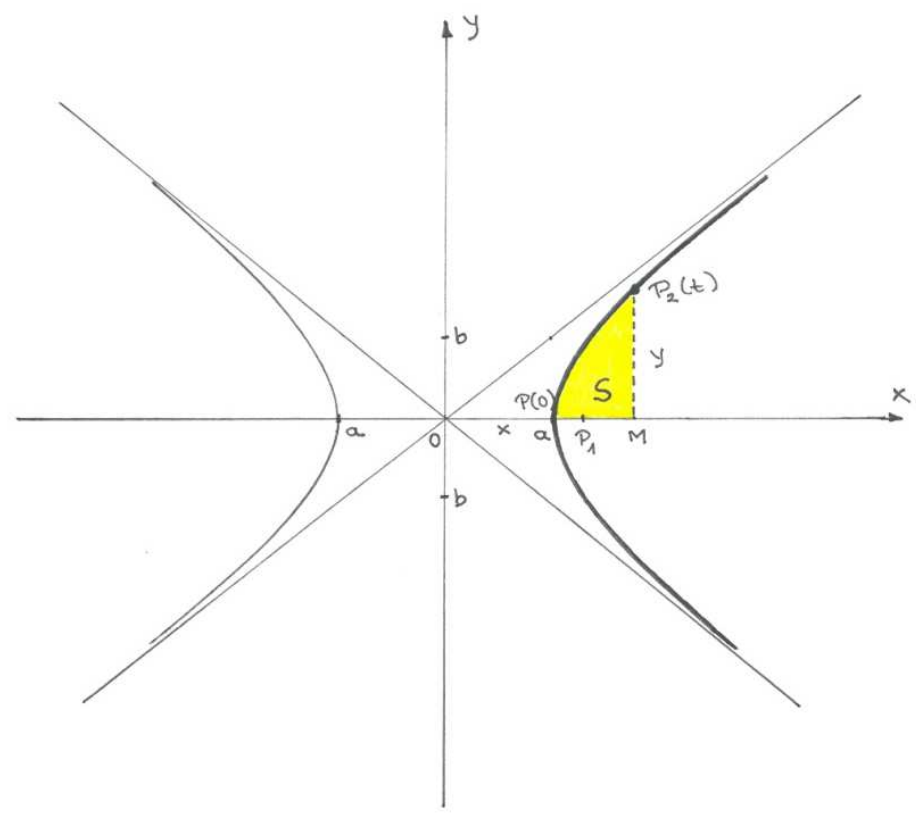

4. ábra. A hiperbola szelet

A $P P_{1} P_{2} \quad S_{H}$ szektor területe (5. ábra):

$$
\begin{aligned}
S_{H} & =S-T_{P_{1} M P_{2} \Delta}=\frac{a \cdot b}{2}(\operatorname{cht} t \cdot \operatorname{sh} t-t)-\frac{1}{2}(a \cdot \operatorname{ch} t-c) \cdot b \cdot \operatorname{sh} t \\
& =\frac{a \cdot b}{2} \cdot(\operatorname{cht} \cdot \operatorname{sh} t-t)-\frac{1}{2}(a \cdot \operatorname{ch} t-e a) \cdot b \cdot \operatorname{sh} t \\
& =\frac{a \cdot b}{2}(\operatorname{cht} t \cdot \operatorname{sh} t-t)-\frac{a \cdot b}{2}(\operatorname{cht} \cdot \operatorname{sh} t-e \cdot \operatorname{sh} t) \\
& =\frac{a \cdot b}{2}(\operatorname{cht} t \cdot \operatorname{sh} t-t-\operatorname{cht} \cdot \operatorname{sh} t+e \cdot \operatorname{sh} t)=\frac{a \cdot b}{2}(e \cdot \operatorname{sh} t-t) .
\end{aligned}
$$

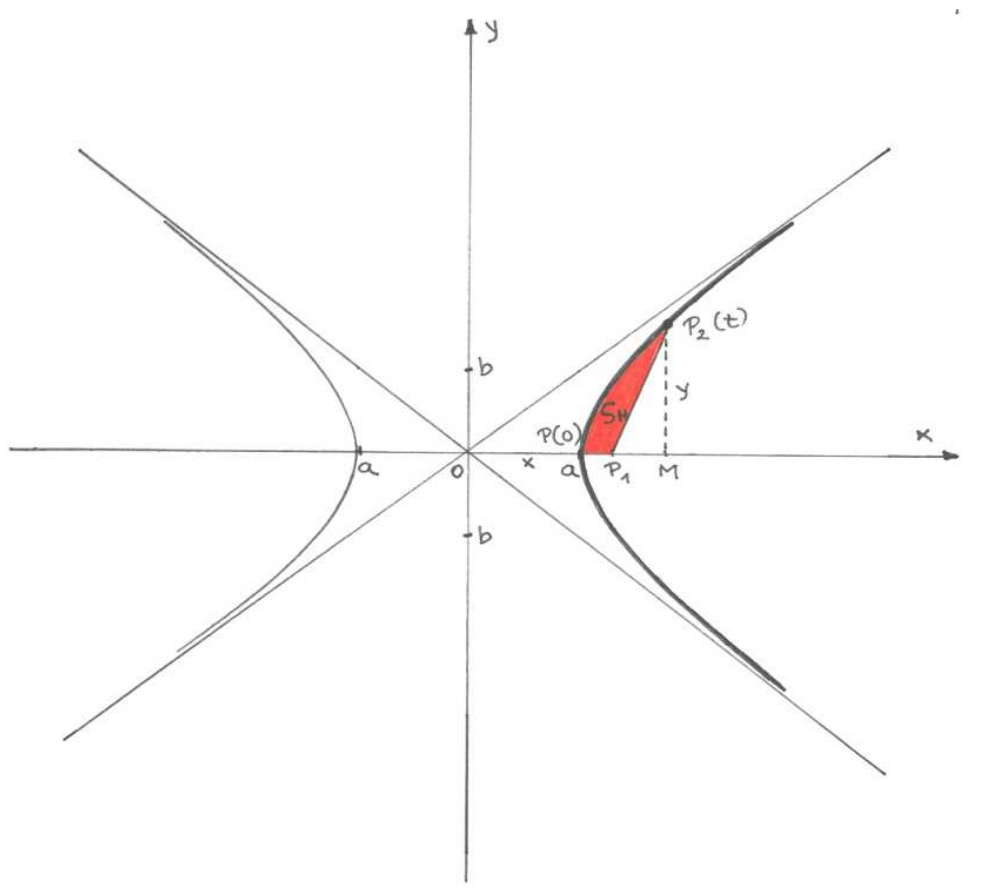

5. ábra. Az $S_{H}$ szektor 
A fentiekben felhasználtuk a kúpszeletek elméletéből közismert eredményeket, amelyek Coxeter (1987) és Hajós (1979) müveiben részletes kifejtésre kerülnek.

Az $S_{H}$ szektor területét azonban meghatározhatjuk az előző fejezetben bemutatott Gaussformula alapján is:

$$
S_{H}=\frac{1}{2} \sqrt{\mu \cdot p} \cdot\left(\tau-\tau_{0}\right)=\frac{1}{2} \sqrt{\mu \cdot \frac{b^{2}}{a}} \cdot\left(\tau-\tau_{0}\right)=\frac{1}{2} b \sqrt{\frac{\mu}{a}} \cdot\left(\tau-\tau_{0}\right) .
$$

A (18) és (19) alapján kiszámított $S_{H}$ kétféle előállítását összevetve

$$
\frac{a \cdot b}{2}(e \cdot \operatorname{sh} t-t)=\frac{1}{2} b \cdot \sqrt{\frac{\mu}{a}} \cdot\left(\tau-\tau_{0}\right)
$$

adódik, amelynek egyszerü azonos átalakításaival

$$
e \cdot \operatorname{sh} t-t=\mu^{\frac{1}{2}} \cdot a^{-\frac{3}{2}} \cdot\left(\tau-\tau_{0}\right)
$$

adódik. Bevezetve az

$$
n:=\mu^{\frac{1}{2}} \cdot a^{-\frac{3}{2}}
$$

mennyiséget az

$$
e \cdot \operatorname{sh} t-t=n\left(\tau-\tau_{0}\right)
$$

összefüggést nyerjük, amely már lényegében a hiperbolikus Kepler-egyenlet.

Az alábbiakban rámutatunk, hogy a (23) összefüggésben elért eredményünk teljes összhangban áll ugyanezen formula szokásosan alkalmazott, differenciálegyenlet megoldásaként nyert végképlettel. A klasszikus, égi mechanikában követett út részletes számításai megtalálhatók Érdi (1996) és Marik (1989) tankönyvében.

A 6. ábra jelöléseit követve elöször egy önmagában is érdekes összefüggést bizonyítunk:

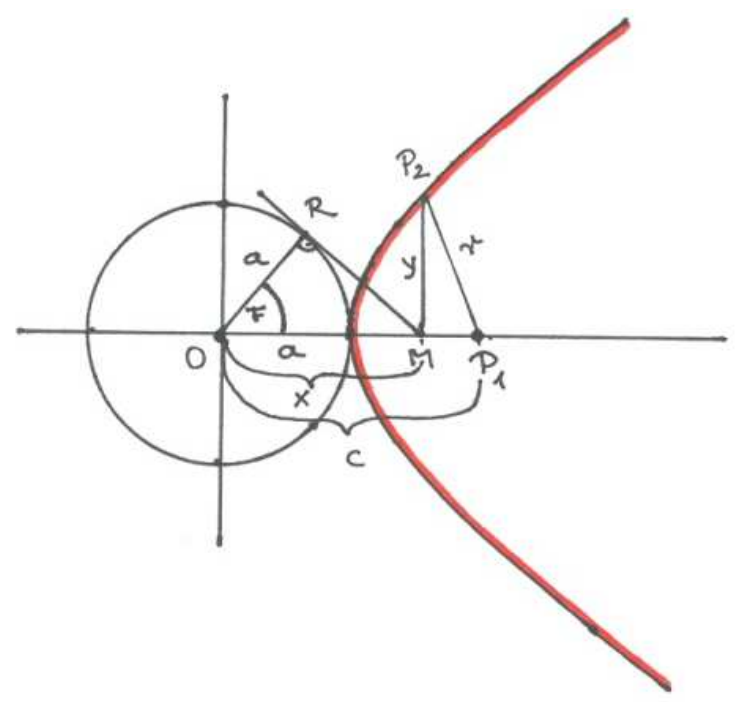


1. Állítás. Ha $H:=\ln \operatorname{tg}\left(\frac{F}{2}+\frac{\pi}{4}\right)$, akkor $\operatorname{sh} H=\operatorname{tg} F$.

Bizonyítás. A $H$ mennyiség definíciójából kiindulva

$$
e^{H}=\operatorname{tg}\left(\frac{F}{2}+\frac{\pi}{4}\right)=\frac{\operatorname{tg} \frac{F}{2}+\operatorname{tg} \frac{\pi}{4}}{1-\operatorname{tg} \frac{F}{2} \cdot \operatorname{tg} \frac{\pi}{4}}=\frac{1+\operatorname{tg} \frac{F}{2}}{1-\operatorname{tg} \frac{F}{2}}
$$

továbbá

$$
e^{-H}=\frac{1}{e^{H}}=\frac{1-\operatorname{tg} \frac{F}{2}}{1+\operatorname{tg} \frac{F}{2}}
$$

adódik. A (24) és (25) felhasználásával

$$
\begin{aligned}
\operatorname{sh} H & =\frac{e^{H}-e^{-H}}{2}=\frac{\frac{1+\operatorname{tg} \frac{F}{2}}{1-\operatorname{tg} \frac{F}{2}}-\frac{1-\operatorname{tg} \frac{F}{2}}{1+\operatorname{tg} \frac{F}{2}}}{2}=\frac{\left(1+\operatorname{tg} \frac{F}{2}\right)^{2}-\left(1-\operatorname{tg} \frac{F}{2}\right)^{2}}{2\left(1-\operatorname{tg} \frac{F}{2}\right) \cdot\left(1+\operatorname{tg} \frac{F}{2}\right)} \\
& =\frac{\left(1+2 \operatorname{tg} \frac{F}{2}+\operatorname{tg}^{2} \frac{F}{2}\right)-\left(1-2 \operatorname{tg} \frac{F}{2}+\operatorname{tg}^{2} \frac{F}{2}\right)}{2\left(1-\operatorname{tg}^{2} \frac{F}{2}\right)}=\frac{4 \operatorname{tg} \frac{F}{2}}{2\left(1-\operatorname{tg}^{2} \frac{F}{2}\right)}=\frac{2 \operatorname{tg} \frac{F}{2}}{1-\operatorname{tg}^{2} \frac{F}{2}}=\operatorname{tg}\left(2 \cdot \frac{F}{2}\right)=\operatorname{tg} F
\end{aligned}
$$

adódik, s pontosan ez az, amit bizonyítani akartunk.

Ezután ismét az 6. ábra jelöléseit felhasználva, s az imént bizonyított állítást felhasználva belátjuk a következőt.

2. Állítás. A (23) összefüggésben szereplő $t$ és az előző állításban bevezetett $H$ paraméterek megegyeznek, azaz $t=H$ teljesül.

Bizonyítás. Az OMR derékszögü háromszögből

$$
\frac{a}{a \cdot \operatorname{cht}}=\cos F
$$

azaz

$$
\operatorname{cht}=\frac{1}{\cos F}
$$

adódik. Szintén az $O M R \Delta$ derékszögü háromszögből a Pitagorasz tétel felhasználásával

$$
a^{2}+(R M)^{2}=x^{2},
$$

vagyis

$$
a^{2}+(R M)^{2}=(a \cdot c h t)^{2}
$$

következik, amelynek egyszerü átrendezésével

$$
R M=\sqrt{a^{2} \cdot c h^{2} t-a^{2}}=a \sqrt{c h^{2} t-1}
$$

adódik. Ismét csak az $O M R \Delta$ derékszögü háromszögből (31) alapján

$$
\sin F=\frac{R M}{x}=\frac{a \cdot \sqrt{c h^{2} t-1}}{a \cdot c h t}=\frac{\sqrt{c h^{2} t-1}}{c h t}
$$


adódik, amelyből (28) és (32) felhasználásával

$$
\operatorname{tg} F=\frac{\sin F}{\cos F}=\operatorname{cht} \cdot \frac{\sqrt{c h^{2} t-1}}{\operatorname{cht}}=\sqrt{\operatorname{ch}^{2} t-1}=\operatorname{sh} t \quad(t>0)
$$

összefüggést nyerjük, ezért előző és mostani állításunk összevetéséből felhasználva az $x \mapsto \operatorname{sh} x$ hiperbolikus függvény szigorúan monoton növekedő voltát

$$
\operatorname{sh} H=\operatorname{tg} F=\operatorname{sh} t
$$

következik, amelyböl azonnal adódik a bizonyítani kívánt $t=H$ egyenlőség.

Ennek eredményeként felírhatjuk a hiperbolikus Kepler-egyenletet a

$$
e \cdot \operatorname{sh} H-H=n\left(\tau-\tau_{0}\right)
$$

szakirodalomból ismert jelölésekben. Ebben az összefüggésben a klasszikus Kepleregyenlethez hasonlóan a (22) összefüggéssel bevezetett $n$ mennyiség megfelel a közepes szögsebességnek, $\tau_{0}$ perihélium átmenet időpontjának, $\tau$ az időnek, $H$ értelmezését pedig az 1. állításban fogalmaztuk meg.

\section{Irodalomjegyzék}

[1] Coxeter, H. S. M., A geometriák alapjai, Müszaki Könyvkiadó, Budapest, 1987.

[2] Érdi B., Égi mechanika, Nemzeti Tankönyvkiadó, Budapest, 1996.

[3] Hajós Gy., Bevezetés a geometriába, Tankönyvkiadó, Budapest, 1979.

[4] Marik M., Csillagászat, Akadémiai Kiadó, Budapest, 1989. 